\title{
Body temperature correlates with mortality in COVID-19 patients
}

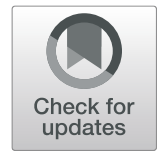

\author{
Serena Tharakan, Koichi Nomoto, Satoshi Miyashita and Kiyotake Ishikawa ${ }^{*}$ (D)
}

Systemic inflammation that accompanies acute respiratory distress syndrome in COVID-19 [1] is associated with a high mortality rate, as high as $32.5 \%$ [2]. Treatment options for severe cases remain limited [3]. The high mortality rate, lack of effective therapies, and extremely high volume of cases have led to a clear need for reliable prognostic markers to indicate which patients are at the highest risk of death and thus require closer monitoring.

One factor that is common to the majority of hospitalized COVID-19 patients is fever. The degree of temperature elevation might reflect the severity of inflammation. However, there are currently no published studies that have looked at body temperature (BT) as a potential prognostic marker. We sought to analyze how BT monitoring might inform mortality rate estimates in COVID-19-positive patients.

We analyzed BT data in the de-identified database of COVID-19-suspected patients in Mount Sinai and its affiliated hospitals in the New York area as of
May 3, 2020. A total of 9417 patients tested positive for the SARS-CoV-2 virus by RT-PCR detection. After excluding patients with missing temperature data $(n=1802), 7614$ patients were included in the analysis (Table 1). Fifty percent had a BT $>37^{\circ} \mathrm{C}$ on the initial presentation and $78.5 \%$ of patients developed $\mathrm{BT}>37^{\circ} \mathrm{C}$ during the course of the disease. The overall mortality was $16.9 \%$ with a median of 7 days to death from the initial presentation. As shown in Fig. 1a, higher BT at the initial presentation did not show a significant association to mortality. Importantly, patients presenting with $\mathrm{BT} \leq 36^{\circ} \mathrm{C}$ had the highest mortality $(26.5 \%, P=0.003$ relative to $36^{\circ} \mathrm{C}<\mathrm{BT} \leq 37^{\circ} \mathrm{C}$ ), and this became even higher when the analysis was restricted to those with $\mathrm{BT} \leq 35.5^{\circ} \mathrm{C}$ (44\%), indicating low body temperature at the initial presentation is a marker of poor prognosis. Meanwhile, maximum BT during COVID-19 infection was significantly correlated with mortality rate (Fig. 1b). There was a significant increase in mortality for every

* Correspondence: kiyotake.ishikawa@mssm.edu

Cardiovascular Research Center, Icahn School of Medicine at Mount Sinai,

One Gustave L. Levy Place, Box 1030, New York, NY 10029-6574, USA

(c) The Author(s). 2020 Open Access This article is licensed under a Creative Commons Attribution 4.0 International License, which permits use, sharing, adaptation, distribution and reproduction in any medium or format, as long as you give appropriate credit to the original author(s) and the source, provide a link to the Creative Commons licence, and indicate if changes were made. The images or other third party material in this article are included in the article's Creative Commons licence, unless indicated otherwise in a credit line to the material. If material is not included in the article's Creative Commons licence and your intended use is not permitted by statutory regulation or exceeds the permitted use, you will need to obtain permission directly from the copyright holder. To view a copy of this licence, visit http://creativecommons.org/licenses/by/4.0/ The Creative Commons Public Domain Dedication waiver (http://creativecommons.org/publicdomain/zero/1.0/) applies to the data made available in this article, unless otherwise stated in a credit line to the data. 
Table 1 Characteristics of patients at first encounter

\begin{tabular}{llll}
\hline & Total population $(n=7614)$ & Died $(n=1286)$ & Alive $(n=6328)$ \\
\hline Age & $59.4 \pm 18.4$ & $73.8 \pm 12.5$ & $56.5 \pm 18.1^{*}$ \\
Sex (\% male) & 54.2 & 59.5 & $53^{*}$ \\
Body mass index & $28.8 \pm 7.4$ & $29.0 \pm 7.8$ & $28.8 \pm 7.3$ \\
Discharged alive (\%) & $/$ & $/$ & 83 \\
Temperature $\left({ }^{\circ} \mathrm{C}\right)$ & $37.0(36.7,37.7)$ & $37.0(36.6,37.7)$ & $37.0(36.7,37.7)$ \\
Systolic blood pressure $(\mathrm{mmHg})$ & $131 \pm 23.2$ & $128.7 \pm 27.8$ & $131.6 \pm 22.0^{*}$ \\
Diastolic blood pressure $(\mathrm{mmHg})$ & $75.3 \pm 13.8$ & $71.7 \pm 15.9$ & $76.1 \pm 13.2^{*}$ \\
Heart rate (BPM) & $95.2 \pm 19.5$ & $96.8 \pm 21.9$ & $94.9 \pm 18.9^{*}$ \\
Oxygen saturation $(\%)$ & $96(94,98)$ & $94(88,97)$ & $97(94,99)^{*}$ \\
\hline
\end{tabular}

Demographic and vitals for 7614 patients who tested positive for the SARS-CoV-2 virus by RT-PCR detection. Data are reported in mean \pm SD, with the exception of oxygen saturation (median, interquartile range (IQR))

${ }^{*} P<0.01$ for those who died vs alive

$0.5^{\circ} \mathrm{C}$ increase in BT, and the mortality was as high as $42 \%$ in those with maximum $\mathrm{BT}>40.0^{\circ} \mathrm{C}$.

Our results indicate that only half of the patients with positive SARS-CoV-2 virus present with $\mathrm{BT}>$ $37^{\circ} \mathrm{C}$ at the initial presentation. However, temperature elevation is common, and high maximum temperature during the course of SARSCoV-2 infection was a significant harbinger of poor outcomes. In fact, one in three patients reaching a maximum $\mathrm{BT}$ above $39.5^{\circ} \mathrm{C}$ died. This was approximately a 5-fold increase in mortality rate as compared to patients whose temperature never broke $37^{\circ} \mathrm{C}$. In contrast, almost half of the patients initially presenting with low BT $\left(<35.5^{\circ} \mathrm{C}\right)$ died. Our results, therefore, suggest that poor BT control during the COVID 19 disease course is a marker of poor prognosis and BT can be used as an easily obtained prognostic indicator.

It remains unknown if controlling the high temperature in severely ill COVID-19 patients would alleviate inflammatory response and improve their outcome. Future studies are necessary to address this question. We acknowledge the limitations of our study including unknown methods of temperature measurement, lack of follow-up of temperature in patients without hospital admission, and that the data is not adjusted for potential confounding factors. Nevertheless, a clear trend in increased mortality among the patients with poor temperature control highlights the usefulness of this noninvasively and easily obtained parameter for evaluating patients' prognoses.

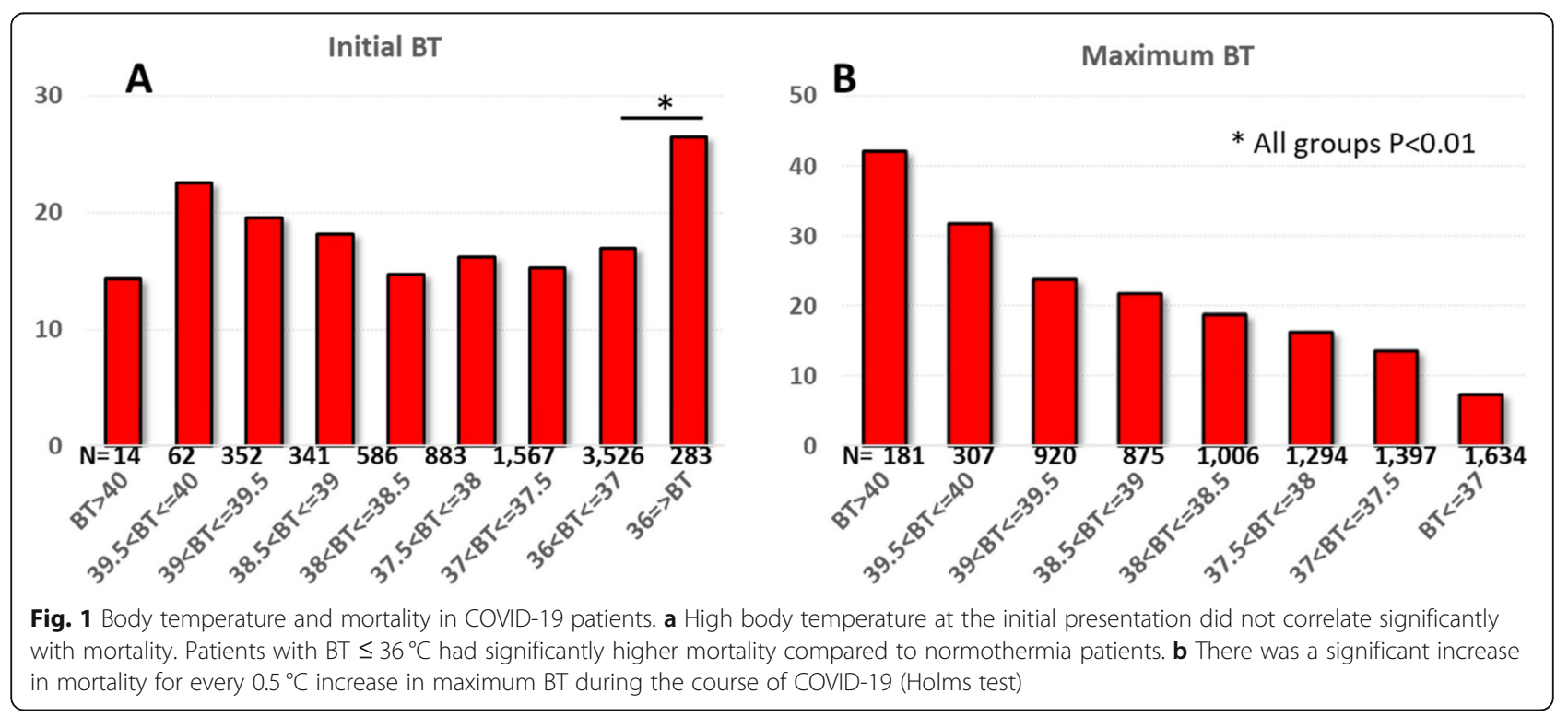




\section{Abbreviation}

BT: Body temperature

\section{Acknowledgements}

None.

\section{Authors' contributions}

ST, KN, and KI conceived and designed the study. ST, SM, and KI analyzed and interpreted the data. ST and Kl drafted the manuscript. All authors revised the manuscript. All authors approved the final version of the manuscript and agreed to authorship contributions.

\section{Funding}

This work was supported by NIH R01 HL139963 (KI) and AHA-SDG

17SDG33410873 (KI).

\section{Availability of data and materials}

The datasets generated and/or analyzed during the current study are not publicly available due to institutional policy but are available from the corresponding author on reasonable request.

\section{Ethics approval and consent to participate}

The IRB at the Icahn School of Medicine at Mount Sinai reviewed the data collection protocol and deemed scientific publication of the de-identified patient information exempt from the IRB review.

\section{Consent for publication}

Not applicable.

\section{Competing interests}

The authors declare that they have no competing interests.

Received: 18 May 2020 Accepted: 28 May 2020

Published online: 05 June 2020

\section{References}

1. Huang C, Wang Y, Li X, et al. Clinical features of patients infected with 2019 novel coronavirus in Wuhan, China. Lancet. 2020;395(10223):497-506.

2. Li X, Xu S, Yu M, et al. Risk factors for severity and mortality in adult COVID-19 inpatients in Wuhan. J Allergy Clin Immunol. 2020;50091-6749(20):30495-4.

3. Cunningham AC, Goh HP, Koh D. Treatment of COVID-19: old tricks for new challenges. Crit Care. 2020;24(1):91.

\section{Publisher's Note}

Springer Nature remains neutral with regard to jurisdictional claims in published maps and institutional affiliations. 